\title{
$\mathrm{Ni}-\mathrm{Zn}$ 레독스 플로우 전지에 있어서 양극의 전기화학적 특성에 미치는 쉬트 형상의 $\mathrm{Ni}$ 나노분말 첨가 효과
}

\author{
석혜원 ${ }^{1,3}$, 김세기 $^{1, a}$, 강양구 $^{1}$, 홍연우 $^{1}$, 이영진 $^{1}$, 김범수 $^{2}$, 주병권 $^{3}$ \\ 1 한국세라믹기술원 전자소재모듈팀 \\ 2 비츠로셀 \\ ${ }^{3}$ 고려대학교 디스플레이 및 나노시스템연구실
}

\section{Addition Effects of Sheet-like Ni Nanopowder on the Electrochemical Properties of Positive Electrode in Ni-Zn Redox Flow Battery}

\author{
Hye-Won Seok ${ }^{1,3}$, Sei-Ki Kim ${ }^{1, a}$, Yang-Koo Kang ${ }^{1}$, Yeon-Woo Hong ${ }^{1}$, Young-Jin Lee ${ }^{1}$, \\ Beom-Su Kim ${ }^{2}$, and Byeong-Kwon $\mathrm{Ju}^{3}$ \\ ${ }^{1}$ Electronic materials \& Module Team, Koewa Institute of Ceramics Engineering and Technology, Seoul 153-801, Korea \\ ${ }^{2}$ Vitzrocell, Seoul 135-703, Korea \\ ${ }^{3}$ Display and Nanosystem Lab, Korea University, Seoul 136-701, Korea
}

(Received July 10, 2014; Revised July 23, 2014; Accepted July 30, 2014)

\begin{abstract}
Co}^{-}$added $\mathrm{Ni}(\mathrm{OH})_{2}$ fine powders, which showed $\beta$-phase, as positive electrode materials have been fabricated using $\mathrm{NiSO}_{4} \cdot 6 \mathrm{H}_{2} \mathrm{O}$ aqueous solution by ultrasonic spray-chemical precipitation and subsequent hydrothermal method, and sheet-like $\mathrm{Ni}$ nanopowder was fabricated by mechano-chemical reduction method. The addition effects of the sheet-like $\mathrm{Ni}$ nanopowder on the electrochemical properties of the positive electrode in Ni-Zn Redox flow battery were investigated. Impedance spectroscopy revealed that the addition of the sheet-like $\mathrm{Ni}$ nanopowder resulted in decrease in the electrical resistivity; $10 \mathrm{wt} . \%$ addition reduced the electrical properties by a fifth. Cyclic voltammetry showed the addition of the sheet-like $\mathrm{Ni}$ nanopowder resulted in decrease in the potential difference of oxidation and reduction; this means the increase in the reversability for electrode reduction. Charge/discharge measurement confirmed that the addition of the sheet-like $\mathrm{Ni}$ nanopowder resulted in the increase in the discharge efficiency.
\end{abstract}

Keywords: $\mathrm{Ni}^{-} \mathrm{Zn}$ Redox flow battery, Sheet-like $\mathrm{Ni}, \mathrm{Co}^{-}$added $\mathrm{Ni}(\mathrm{OH})_{2}$, Impedance spectroscopy

\section{1. 서 론}

a. Corresponding author; kimseiki@kicet.re.kr

Copyright (C2014 KIEEME. All rights reserved.

This is an Open-Access article distributed under the terms of the Creative Commons Attribution Non-Commercial License (http://creativecommons.org/licenses/by-nc/3.0) which permits unrestricted non-commercial use, distribution, and reproduction in any medium, provided the original work is properly cited.
최근 전력 수요-공급의 불일치로 정전 피해가 속출 하고 있다. 이러한 단기적인 정전 피해를 최소화하며 중장기적으로는 효율적인 전력 활용, 고품질의 전력 확보, 안정적인 전력 공급 측면으로 비상전원인 에너 지저장시스템 필요성이 증대되고 있다. 에너지 저장 시스템 (energy storage system, ESS)이란 생산된 전 력을 저장했다가 전력이 가장 필요한 시기에 공급하 
여 에너지 효율을 높이는 시스템으로서, 전기를 저장 하는 역할을 하는 전지가 핵심부품으로서, 이러한 대 규모 전력 저장을 위해 $\mathrm{NaS}$ 전지나 flow 전지에 대 한 연구가 진행되고 있다 [1-6]. $\mathrm{NaS}$ 전지는 $300^{\circ} \mathrm{C}$ 이상의 고온의 황과 용융된 나트륨을 이용하는 전지 로서 일본의 $\mathrm{NGK}$ 사가 실제 $\mathrm{ESS}$ 를 설치한 사례가 있으나, 설비를 고온에서 운용해야 한다는 점과 유해 물질인 황을 사용한다는 단점이 있다. V계 Redox flow 전지 [7-9]는 $\mathrm{Ni}$ 계에 비해 연구가 많이 진행되 었고, 한 종류의 전극을 사용하므로 간단한 방법으로 제작이 가능하다는 장점이 있으나, 두 종류의 전해질 사용으로 인해 고가의 이온교환막이 필요하며, 황산 의 전해질을 사용하므로 친환경적이지 못하다는 단점 이 있다. 이에 비하여 $\mathrm{Ni}-\mathrm{Zn}$ 계 Redox flow 전지 [10-15]는 한 종류의 전해질을 사용하기 때문에 두 종류의 전해질을 사용하는 기존의 $\mathrm{V}$ 계열의 전지에 비하여 셀 구조의 단순화시킬 수 있으며 친환경적이 라는 장점이 있으나, 아직 연구단계가 초기로서 $\mathrm{Ni}(\mathrm{OH})_{2}$ 양극의 열화 억제 및 음극의 $\mathrm{Zn}$ 석출 제어 등의 연구를 통한 사이클 수명 특성 향상이 해결되어 야 한다. Ni-Zn Redox flow battery는 $\mathrm{Ni}(\mathrm{OH})_{2}$ 를 양 극의 소재로 사용하고 있으며 소재의 방전 특성 향상 을 위하여 $\mathrm{Co}, \mathrm{Mn}$, 및 $\mathrm{Ni}$ 등을 첨가하여 $\mathrm{Ni}(\mathrm{OH})_{2}$ 의 양극 특성 향상을 위한 연구는 $\mathrm{Ni}-\mathrm{MH}$ 전지 등을 중 심으로 널리 진행되어 왔다 [16-19].

본 연구에서는 Redox flow 전지의 양극소재로 사 용하기 위하여 $3 \mathrm{~mol} \% \mathrm{Co}$ 가 첨가된 $\mathrm{Ni}(\mathrm{OH})_{2}$ 를 제조 하였으며, 쉬트 형상의 $\mathrm{Ni}$ 나노분말을 기계 화학적 환원법 (mechanochemical reduction method)으로 제 조하여 양극의 전기화학적 특성에 대한 첨가 효과를 고찰하였다.

\section{2. 실험 방법}

\section{$2.13 \mathrm{~mol} \% \mathrm{Co}$ 첨가 $\mathrm{Ni}(\mathrm{OH})_{2}$ 분말의 합성}

수산화니켈 분말은 $130 \mathrm{kHz}$ 주파수의 초음파 분무 -화학침전법과 수열합성법을 통하여 제조하였다. 먼 저 $\mathrm{Ni}$ 양이온의 원료로 $0.97 \mathrm{M}$ 의 $\mathrm{NiSO}_{4} \cdot 6 \mathrm{H}_{2} \mathrm{O}$ (99.5\%, Kanto Chemical, Japan)와 $0.03 \quad \mathrm{M}$ 의 $\mathrm{Co}\left(\mathrm{NO}_{3}\right)_{2} \cdot 6 \mathrm{H}_{2} \mathrm{O}$ (99.9\%, Junsei, Japan)를 증류수에 용해시켜 $1 \mathrm{~L}$ 용량으로 초음파 분무에 사용할 $\mathrm{Ni}$ 염 용액을 제조하였다. 화학침전을 위한 알칼리 성분 원
료로는 $2 \mathrm{M}$ 의 $\mathrm{KOH}$ (99.8\%, Daejung, Korea)를 증류 수에 용해시켜 제조하였다. $\mathrm{KOH}$ 용액을 $500 \mathrm{rpm}$ 의 속도로 교반하며, 황산니켈염 용액을 $130 \mathrm{kHz}$ 주파수 의 초음파 분무장치를 통하여 $20 \mathrm{~m} / / \mathrm{min}$ 의 속도로 $500 \mathrm{rpm}$ 의 속도로 교반되는 $\mathrm{KOH}$ 용액에 분사시켜 3 $\mathrm{mol} \% \mathrm{Co}$ 가 첨가된 $\mathrm{Ni}(\mathrm{OH})_{2}$ 침전물을 합성하였고, 여과액이 중성을 나타낼 때까지 증류수로 수차례 반 복 여과, 건조를 통하여 분말을 얻었다. 이러한 분말 을 $500 \mathrm{ml}$ 용량의 PTFE (poly tetra fluoro ethylene) 재질의 용기 담아 오토 클레이브에서 $120^{\circ} \mathrm{C}$ 에서 24 시 간 동안 수열 합성을 행하였다. 수열 합성 후 다시 증류수로 알칼리 양이온 등의 불순물을 제거한 후, $80^{\circ} \mathrm{C}$ 에서 24 시간 동안 건조하여 양극 제조용 원료로 하였 다.

\section{2 쉬트 형상 $\mathrm{Ni}$ 나노 분말의 합성}

$3 \mathrm{~mol} \% \mathrm{Co}$ 가 첨가된 $\mathrm{Ni}(\mathrm{OH})_{2}$ 양극의 전기화학적 특성에 대한 쉬트 형상의 니켈 나노 분말의 첨가 효 과 고찰을 위하여 기계화학적 환원법으로 $\mathrm{Ni}$ 금속분 말을 제조하였는데, 이는 환원제로서 $\mathrm{NaBH}_{4}(99.5 \%$, Daejung, Korea)로 사용하여 기계적 혼합에 의하여,

$$
\mathrm{NiCl}_{2}+2 \mathrm{NaBH}_{4} \rightarrow \mathrm{Ni}+2 \mathrm{NaCl}+\mathrm{B}_{2} \mathrm{H}_{6} \uparrow+\mathrm{H}_{2} \uparrow
$$

의 환원반응에 의해 $\mathrm{Ni}$ 금속을 제조하는 것으로서, 본 연구에서는 $\mathrm{NiCl}_{2} \cdot 6 \mathrm{H}_{2} \mathrm{O}$ 에 이론값 (2배 몰수) 보 다 약간 많은 2.2 배 몰수의 $\mathrm{NaBH}_{4}$ 를 혼합하여 $\mathrm{NaBH}_{4}$ 를 자발적 분해 반응을 억제하기 위하여 이소 프로필 알콜을 첨가하여 유발에서 30분 간 혼합하여 얻어진 생성물에서 불순물인 $\mathrm{NaCl}$ 을 제거하기 위하 여 여과액에서 $\mathrm{AgNO}_{3}$ 에 의한 염소이온이 검출되지 않을 때까지 반복 여과한 후, $80^{\circ} \mathrm{C}$ 에서 24시간 동안 건조시켜 얻은 반응물을 $400^{\circ} \mathrm{C}$ 에서 1 시간 동안 $3 \%$ 수소 분위기에서 열처리 및 응집체의 해쇄를 통하여 $\mathrm{Ni}$ 나노 분말을 제조하였다.

\section{3 양극의 제조}

양극의 전기화학적 특성에 대한 $\mathrm{Ni}$ 나노분말의 첨 가 효과를 고찰하기 위하여 전체 양극물질 조성의 0 , $5,10 \mathrm{wt} \%$ 의 비율로 $\mathrm{Ni}$ 나노 분말을 첨가하여 양극 을 제조하였다. $3 \mathrm{~mol} \% \mathrm{Co}$ 를 첨가한 $\mathrm{Ni}(\mathrm{OH})_{2}$ 는 모 두 $50 \mathrm{wt} \%$ 의 비율로 동일하였으며, $\mathrm{Ni}$ 나노 분말 비 
울의 증가에 따라 graphite의 양을 45, 40, $35 \mathrm{wt} \%$ 로 혼합하였다. $\mathrm{Ni}(\mathrm{OH})_{2}$ 전극의 전도성을 확보하기 위하 여 각 전극에 $5 \mathrm{wt} \%$ 의 Carbon Black (JD600 K)를 혼 합하였다. 바인더로서 PTFE 6\% 수용액을 전체 양극 소재의 무게 대비 $5 \mathrm{wt} \%$ 로 첨가하였다. 혼합시킨 시료 를 일정한 두께로 제조 후 집전체로서 기공조밀도 110 PPI (pore per inch)의 $\mathrm{Ni}$ 폼에 담지하여 $80^{\circ} \mathrm{C}$ 에서 15 분 간 $3 \mathrm{MPa}$ 로 압착 및 건조하여 전극을 제작하였다.

\section{4 단전지 셀 제작 및 특성 평가}

$\mathrm{Ni}(\mathrm{OH})_{2}$ 및 $\mathrm{Ni}$ 나노 분말의 결정상을 확인하기 위 하여 X-ray diffraction (Rigaku D MAX2200, Japan, $\mathrm{Cu} K \mathrm{Ka}, 40 \mathrm{kV} / 30 \mathrm{~mA}$ )를 사용하여 결정상을 측정하 였고, $\mathrm{XRD}$ 측정 범위는 $10^{\circ} \sim 70^{\circ}$ 구간에서 $0.02^{\circ}$ 의 간격으로 진행하였다. Brunauer - Emmett - Teller (Tristar 3000, Micremeritics, USA) 법으로 $\mathrm{Ni}(\mathrm{OH})_{2}$ 분말의 비표면적을 측정하였다. SEM과 TEM을 이용 하여 $\mathrm{Ni}(\mathrm{OH})_{2}$ 및 $\mathrm{Ni}$ 나노 분말의 미세구조를 관찰 하였다.

$\mathrm{Ni}(\mathrm{OH})_{2}$ 전극에서의 $\mathrm{Ni}$ 나노 분말 첨가에 대한 전 기 화학적 특성을 평가하기 위하여 각 조성으로 제작 한 $\mathrm{Ni}(\mathrm{OH})_{2}$ 전극을 임피던스 (Zive SP2, Zive lab)를 측정하여 전극 저항을 측정하였다. 측정 주파수는 10 $\mathrm{mHz} \sim 100 \mathrm{kHz}$ 구간에서 측정하였으며 amplitude voltage는 $5 \mathrm{mV}$ 로 하였다. 제조한 양극의 산화/환원 전위 측정은 $5 \mathrm{mV} / \mathrm{s}$ 의 스캔 속도로 $\mathrm{C}-\mathrm{V}$ (Zive $\mathrm{SP} 2$, Zive lab)로 행하였는데, 상대전극은 Pt plate를 사용 하였고 전해액은 $6 \mathrm{M}$ 의 $\mathrm{KOH}$ 용액을 사용하였고, 기 준전극으로 $\mathrm{Hg} / \mathrm{HgO}$ 표준전극을 사용하였다. 또한, 각 조성별 양극의 충방전 특성을 평가하기 위하여 단 전지 셀을 제작하여 $8 \mathrm{M}$ 의 $\mathrm{KOH}$ 용액을 전해액으로 충방전 특성을 평가하였다. 상대 전극은 기공조밀도 $110 \mathrm{PPI}$ 의 $\mathrm{Ni}$ 폼을 사용하였고, $\mathrm{Hg} / \mathrm{HgO}$ 기준 전극 을 사용하여 충방전 시의 전체 셀과 함께 양극의 충 방전 거동도 동시에 관찰하였다. 모든 조성의 전극은 $2 \mathrm{C}\left(1 \mathrm{C}=\mathrm{Ni}(\mathrm{OH})_{2}\right.$ 이론 용량 $(289 \mathrm{~mA} / \mathrm{g})$ 의 전류밀도로 1 시간 충전)의 속도로 30 분 간 충방전을 행하였으며, cut-off 전압은 $0.8 \mathrm{~V}$ 로 설정하였다.

\section{3. 결과 및 고찰}

$130 \mathrm{kHz}$ 의 주파수로 초음파분무-화학침전법 및 추

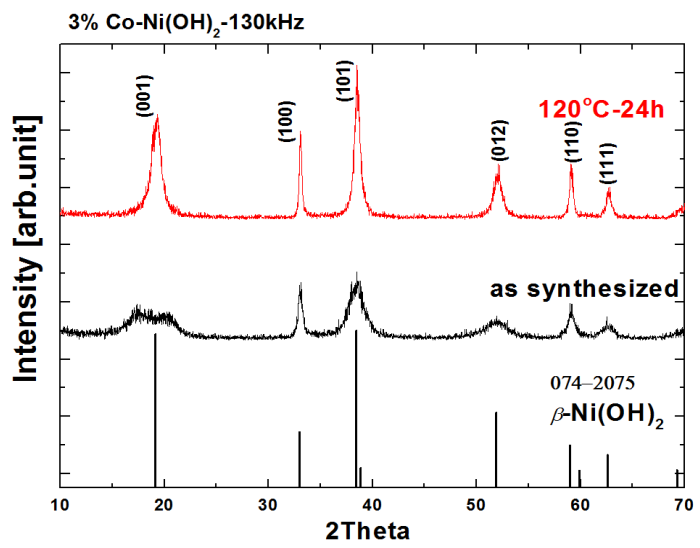

Fig. 1. XRD patterns of $\mathrm{Co}^{-}$added $\mathrm{Ni}(\mathrm{OH})_{2}$ powders.



Fig. 2. XRD patterns of Ni metal nanopowders.

가적인 수열합성을 통하여 제조한 $3 \mathrm{~mol} \% \mathrm{Co}$ 가 첨 가된 $\mathrm{Ni}(\mathrm{OH})_{2}$ 분말의 $\mathrm{XRD}$ 에 의한 결정상 분석 결과 를 그림 1 에 나타내었다. $130 \mathrm{kHz}$ 의 초음파 분무 화 학침전법으로 합성한 $\mathrm{Ni}(\mathrm{OH})_{2}$ 분말의 결정성은 미약 한 $\beta$ 상의 $\mathrm{Ni}(\mathrm{OH})_{2}$ 가 관찰되었으며, 이를 $120^{\circ} \mathrm{C}$ 에서 24 시간 동안 수열 합성한 결과, 결정성이 대폭 향상 되었다. 특히 (001) 면의 회절피크가 매우 향상된 것 을 통해 결정 $c$ 축을 따라 층상구조를 가지는 $\beta$ $-\mathrm{Ni}(\mathrm{OH})_{2}$ 의 c축 방향의 구조가 규칙적으로 바뀌었다 는 것을 알 수 있다.

그림 2는 기계화학적 환원법으로 제조한 $\mathrm{Ni}$ 나노분 말의 $\mathrm{X}$ 선 회절에 의한 결정상 분석을 나타낸 것이다. 합성 직후는 비정 질을 나타내며, $400^{\circ} \mathrm{C}$ 에서 1 시간 $3 \%$ 의 수소 분위기에서 열처리에 의해 양호한 $\mathrm{Ni}$ 금속 결정성을 나타냄을 확인할 수 있다. 

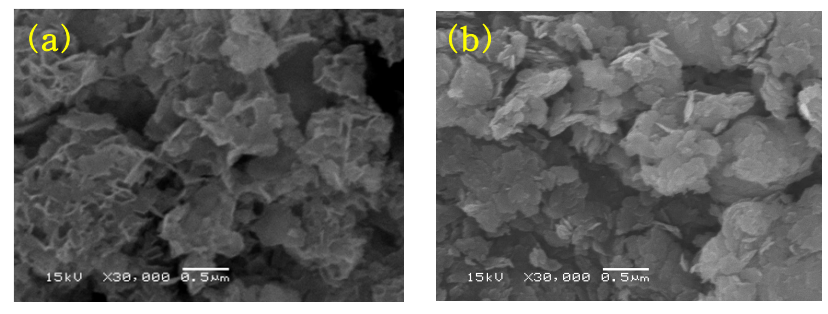

Fig. 3. SEM image of (a) as - synthesized $\mathrm{Ni}(\mathrm{OH})_{2}$ powder (130 $\mathrm{kHz}$ ultrasonic) and (b) $\mathrm{Ni}(\mathrm{OH})_{2}$ powder by hydrothermal.

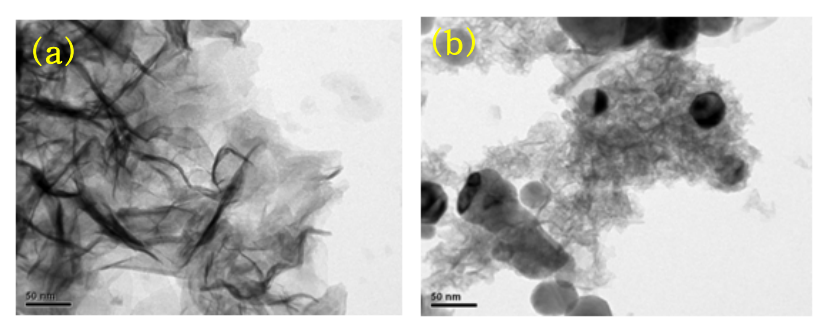

Fig. 4. TEM image of (a) as synthesized Ni nanopowder and (b) Ni nanopowder by thermal treatment.

그림 3 은 $\mathrm{Ni}(\mathrm{OH})_{2}$ 분말의 미세구조를 $\mathrm{SEM}$ 으로 관찰한 결과를 나타낸다. $130 \mathrm{kHz}$ 의 초음파 화학 침 전 합성 직후의 $\mathrm{Ni}(\mathrm{OH})_{2}$ 분말은 $20 \mathrm{~nm}$ 크기의 나노 쉬트 및 판상이 혼재된 형상을 나타내었으며, $120^{\circ} \mathrm{C}$ 에서 24 시간 동안 수열 합성한 $\mathrm{Ni}(\mathrm{OH})_{2}$ 분말의 경우 $3 \sim 50 \mathrm{~nm}$ 크기의 전형적인 육각 판상형 $\beta-\mathrm{Ni}(\mathrm{OH})_{2}$ 형상을 이루었음을 확인할 수 있다.

그림 4 는 $\mathrm{Ni}$ 나노분말의 미세구조를 $\mathrm{TEM}$ 으로 관 찰한 결과를 나타낸다. 합성 직후의 $\mathrm{Ni}$ 분말은 뚜렷 한 나노 쉬트의 형상을 나타내었으며, $400^{\circ} \mathrm{C}$ 에서 1 시 간 동안 $3 \%$ 수소 분위기에서 열처리한 후에도 일부 는 입자화가 되었으나 대부분 나노 쉬트 형상을 유지 하고 있음을 확인할 수 있다.

다음의 $\mathrm{Ni}(\mathrm{OH})_{2}$ 분말의 비표면적 및 입자 크기를 표 1 에 정리하였다. $130 \mathrm{kHz}$ 의 초음파 화학 침전법에 의해 합성된 $\mathrm{Ni}(\mathrm{OH})_{2}$ 분말은 $380 \mathrm{~m}^{2} / \mathrm{g}$ 의 높은 비표면 적을 나타내었으나, 이를 $120^{\circ} \mathrm{C}$ 에서 24 시간 동안 수 열 합성한 결과, 비표면적은 $120 \mathrm{~m}^{2} / \mathrm{g}$ 으로 떨어졌으 나 입자의 크기가 $50 \mathrm{~nm}$ 로 증가한 것을 확인할 수 있었다. 본 연구에서는 수열합성을 통해 $\mathrm{Ni}(\mathrm{OH})_{2}$ 결 정성 및 입자의 크기를 향상시킨 분말을 사용하여 전 극을 제조하였다.
Table 1. Summary of physical properties of $\mathrm{Ni}(\mathrm{OH})_{2}$ powder.

\begin{tabular}{|c|c|c|}
\hline Item & $\begin{array}{c}\text { Specific surface } \\
\text { area }\left[\mathrm{m}^{2} / \mathrm{g}\right]\end{array}$ & Particle size [nm] \\
\hline $\begin{array}{c}\text { as synthesized } \\
3 \mathrm{mo} \% \mathrm{Co}^{-} \mathrm{Ni}(\mathrm{OH})_{2} \\
\end{array}$ & 380 & 20 \\
\hline $\begin{array}{c}3 \mathrm{~mol} \% \mathrm{Co}^{-} \mathrm{Ni}(\mathrm{OH})_{2} \\
\text { by hydrothermal }\end{array}$ & 120 & $3 \sim 50$ \\
\hline
\end{tabular}

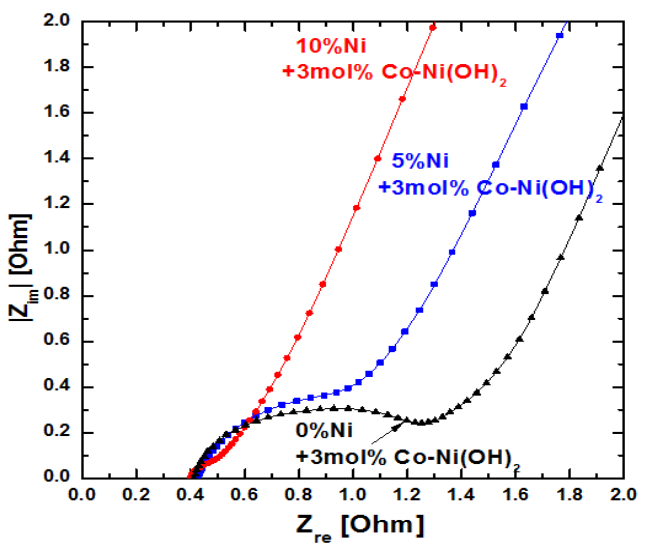

Fig. 5. Impedance plots of $\mathrm{Ni}(\mathrm{OH})_{2}$ electrodes.

그림 5 는 $3 \mathrm{~mol} \% \mathrm{Co}$ 첨가 $\mathrm{Ni}(\mathrm{OH})_{2}$ 에 쉬트 형상의 $\mathrm{Ni}$ 나노분말을 첨가하여 제작한 전극의 임피던스 분 석에 의한 전기저항 측정 결과를 나타낸다. $\mathrm{Ni}$ 나노 분말을 첨가하지 않은 경우, 약 $1.0 \Omega \cdot \mathrm{cm}$ 의 전기저 항을 나타내지만 $\mathrm{Ni}$ 분말을 $5 \%$ 첨가한 전극의 저항 은 $0.6 \Omega \cdot \mathrm{cm}, 10 \%$ 의 첨가의 경우, $0.2 \Omega \cdot \mathrm{cm}$ 으로 서 전기 저항이 첨가량에 따라서 지속적으로 감소함 을 알 수 있는데, 쉬트 형상의 $\mathrm{Ni}$ 나노분말의 첨가는 소량 첨가에도 불구하고 비교적 전기전도성이 낮은 수산화니켈의 전도패스를 효과적으로 형성하여 전극 저항을 감소시키는 것을 확인할 수 있고, 이는 Girish S. Gund의 임피던스에 의한 $\mathrm{Ni}(\mathrm{OH})_{2}$ 전극의 저항은 $0.65 \Omega \cdot \mathrm{cm}$ 였으며, J. Lang 등의 연구 결과에 의한 $\mathrm{Ni}(\mathrm{OH})_{2}$ 전극의 저항은 $1.6 \Omega \cdot \mathrm{cm}$ 으로 $\mathrm{Ni}$ 나노 쉬 트 첨가에 의해 기존의 연구보다 낮은 저항 값을 나 타내었다 [21,22].

그림 6은 각 조성별 $3 \mathrm{~mol} \% \mathrm{Co}$ 첨가 $\mathrm{Ni}(\mathrm{OH})_{2}$ 전극 을 $\mathrm{C}-\mathrm{V}$ 측정에 의해 산화전위 $\left[\mathrm{E}_{\mathrm{O}}\right]$ 및 환원전위 $\left[\mathrm{E}_{\mathrm{R}}\right]$ 를 측정한 결과를 나타낸다. 산화/환원전위 $\left[\mathrm{E}_{\mathrm{O}}-\mathrm{E}_{\mathrm{R}}\right]$ 의 
Table 2. Summary of electrochemical properties of $\mathrm{Ni}(\mathrm{OH})_{2}$ electrodes.

\begin{tabular}{|c|c|c|c|c|c|c|c|c|}
\hline Item & $\begin{array}{c}\mathrm{R} \\
{[\Omega \cdot \mathrm{cm}]}\end{array}$ & $\begin{array}{l}\mathrm{E}_{\mathrm{O}} \\
{[\mathrm{V}]}\end{array}$ & $\begin{array}{c}E_{R} \\
{[V]}\end{array}$ & $\begin{array}{c}\mathrm{E}_{\mathrm{O}}-\mathrm{E}_{\mathrm{R}} \\
{[\mathrm{V}]}\end{array}$ & $\begin{array}{l}\text { Discharge } \\
\text { Capacity } \\
{[\mathrm{mAh} / \mathrm{g}]}\end{array}$ & $\begin{array}{c}\text { Discharge } \\
\text { Efficiency } \\
{[\%]}\end{array}$ & $\begin{array}{c}\text { Discharge } \\
\text { Energy Density } \\
{[\mathrm{mW} / \mathrm{g}]}\end{array}$ & $\begin{array}{c}\text { Discharge } \\
\text { Energy Density } \\
\text { Efficiency } \\
{[\%]}\end{array}$ \\
\hline $\begin{array}{c}0 \% \mathrm{Ni}^{-} \\
3 \mathrm{mo} \% \mathrm{Co}^{-} \mathrm{Ni}(\mathrm{OH})_{2} \\
\end{array}$ & 1.0 & 0.554 & 0.239 & 0.314 & 238 & 82.4 & 361 & 67.5 \\
\hline $\begin{array}{c}\% \mathrm{Ni}^{-} \\
3 \mathrm{~mol} \% \mathrm{Co}^{-} \mathrm{Ni}(\mathrm{OH})_{2} \\
\end{array}$ & 0.6 & 0.542 & 0.258 & 0.284 & 240 & 83.3 & 381 & 71.2 \\
\hline $\begin{array}{c}10 \% \mathrm{Ni}^{-} \\
3 \mathrm{~mol} \% \mathrm{Co}^{-} \mathrm{Ni}(\mathrm{OH})_{2} \\
\end{array}$ & 0.2 & 0.525 & 0.271 & 0.254 & 253 & 87.4 & 420 & 78.5 \\
\hline
\end{tabular}



Fig. 6. Cyclic voltammograms of $\mathrm{Ni}(\mathrm{OH})_{2}$ electrodes.

차이는 전극반응의 가역성을 나타내는 것으로서, 그 차이가 작을수록 전극 반응의 가역성이 용이하다 [23]. 쉬트 형상의 $\mathrm{Ni}$ 나노분말을 첨가하지 않은 $\mathrm{Ni}(\mathrm{OH})_{2}$ 전극의 경우, $\mathrm{E}_{\mathrm{O}}$ 가 $0.554 \mathrm{~V}, \mathrm{E}_{\mathrm{R}}$ 가 $0.239 \mathrm{~V}$ 그 차이 $\left[\mathrm{E}_{\mathrm{O}}-\mathrm{E}_{\mathrm{R}}\right]$ 값 $0.314 \mathrm{~V}$ 를 나타낸 반면, $5 \%$ 의 $\mathrm{Ni}$ 분말을 첨가한 경우, 산화/환원전위 차이가 $0.284 \mathrm{~V}$, $10 \% \mathrm{Ni}$ 분말을 첨가한 경우는 $\left[\mathrm{E}_{\mathrm{O}}-\mathrm{E}_{\mathrm{R}}\right]$ 이 $0.254 \mathrm{~V}$ 로 서 $\mathrm{Ni}$ 분말을 첨가에 따라서 지속적으로 산화/환원전 위 차이가 감소함을 알 수 있다.

본 연구에서 첨가한 쉬트 형상의 전기적 특성이 우 수한 $\mathrm{Ni}$ 나노 분말을 첨가함으로 인하여 양극은 충분 한 전도성을 확보하여 이온과 전자의 이동이 용이하 도록 전기장 형성 및 전도패스 형성으로 인하여 $\mathrm{Ni}$ 나노 분말을 첨가하지 않은 전극에 비해 $\mathrm{Ni}^{2+}(\mathrm{OH})_{2} \leftrightarrow$ $\mathrm{Ni}^{3+} \mathrm{OOH}$ 의 산화/환원 반응이 원활하게 이루어짐을 알 수 있다. 각 조성별 전극의 임피던스 및 $\mathrm{C}-\mathrm{V}$ 측 정에 대한 결과를 표 2 에 요약하였다.
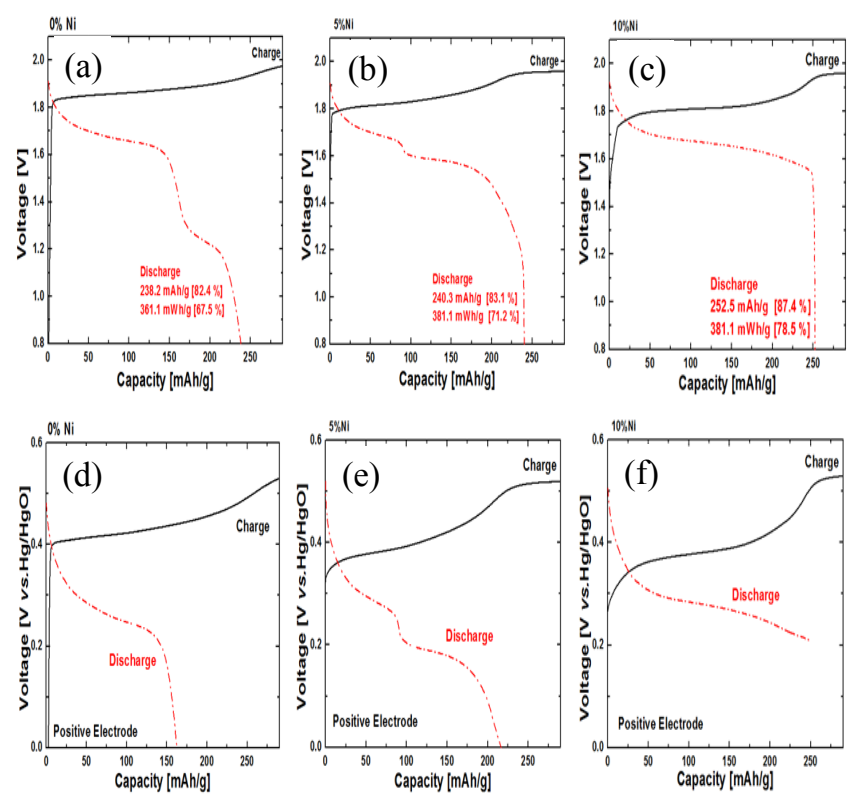

Fig. 7. Charge-discharge behavior of $\mathrm{Ni}^{-} \mathrm{Zn}$ redox flow battery of (a) $0 \% \mathrm{Ni}^{-}$, (b) $5 \% \mathrm{Ni}^{-}$, (c) $10 \% \mathrm{Ni}$-added single cell, and potential of the positive electrode of (d) (a)-cell, (e) (b)-cell, and (f) (c)-cell.

단전지 셀의 전기화학적 특성 및 충, 방전 특성을 표 2 와 그림 $7(\mathrm{a} \sim \mathrm{c})$ 에 나타내었다. $\mathrm{Ni}$ 분말을 첨가하 지 않은 전극을 양극으로 사용한 경우의 방전 용량은 $238 \mathrm{mAh} / \mathrm{g}$ 으로서 방전 효율 및 에너지밀도 효율은 $82.4 \%$ 와 $67.5 \%$ 를 나타냈으며, $5 \% \mathrm{Ni}$ 분말을 첨가한 경우의 방전용량은 $240 \mathrm{mAh} / \mathrm{g}$ 으로서 각각 $83.3 \%$ 와 $71.2 \%$ 로 약간 증가하는 것을 알 수 있다. $10 \% \mathrm{Ni}$ 을 첨가한 전극의 경우, 방전용량은 $253 \mathrm{mAh} / \mathrm{g}$ 를 나타 내어 $87.4 \%$ 의 방전 효율과 $78.5 \%$ 의 방전 에너지 밀 
도 효율을 나타내어, $\mathrm{Ni}$ 분말 첨가에 의한 단전지 셀 에서의 에너지 효율 향상을 확인할 수 있었다.

이러한 $\mathrm{Ni}$ 분말을 첨가한 양극의 방전 효율과 에너 지밀도 효율의 향상 이유를 확인하기 위하여 충 방전 시 양극의 포텐셜을 측정한 결과를 그림 $6(\mathrm{~d} \sim \mathrm{f})$ 에 나 타내었다. 먼저 충전 시에는 $\mathrm{Ni}$ 나노 분말을 첨가한 양극의 포텐셜이 충전 시작과 동시에 급격히 상승하 는 현상이 관찰되었는데, 이는 양극의 낮은 전기저항 으로 인하여 셀의 분극이 보다 원활하게 이루어지는 것에 기인하는 것으로 사료된다. 또한, 방전 시에는 $\mathrm{Ni}$ 나노 분말을 첨가하지 않은 경우의 셀의 방전 용 량이 $150 \mathrm{mAh} / \mathrm{g}$ 이상에서, 양극의 전압 강하가 급격 히 일어나서 $0 \mathrm{~V}$ 수준까지 떨어지는 것이 관찰되었 으나, $\mathrm{Ni}$ 나노 분말을 첨가한 양극의 경우 방전 시, 약 $0.2 \mathrm{~V}$ 를 유지하던 양극의 전압 강하는 200 $\mathrm{mAh} / \mathrm{g}$ 이 방전된 이후에 발생하였으며, 특히 $10 \% \mathrm{Ni}$ 이 첨가된 양극의 경우, 방전 시에 양극의 포텐셜이 $0.2 \mathrm{~V} \sim 0.3 \mathrm{~V}$ 로 지속적으로 유지하는 것이 관찰되었 는데, 이로 인하여 에너지밀도 효율이 향상된다는 것 을 확인할 수 있었다. 극의 경우 방전 시, 약 $0.2 \mathrm{~V}$ 를 유지하던 양극의 전압 강하는 $200 \mathrm{mAh} / \mathrm{g}$ 이 방전된 이후에 발생하였으며, 특히 $10 \% \mathrm{Ni}$ 이 첨가된 양극의 경우, 방전 시에 양극의 포텐셜이 $0.2 \mathrm{~V} \sim 0.3 \mathrm{~V}$ 로 지 속적으로 유지하는 것이 관찰되었는데, 이로 인하여 에너지밀도 효율이 향상된다는 것을 확인할 수 있었 다.

\section{4. 결 론}

본 연구에서는 $\mathrm{Ni}-\mathrm{Zn}$ 레독스 플로우 전지의 양극 소재로서 초음파분무-화학침전 반응과 추가적인 수열 합성법을 이용하여 $3 \mathrm{~mol} \%$ 의 코발트를 첨가한 $\mathrm{Ni}(\mathrm{OH})_{2}$ 를 제조하였으며, 쉬트 형상의 $\mathrm{Ni}$ 나노분말을 기계화학적 환원법으로 제조하여 양극 소재에 대한 첨가 효과를 전극 및 단전지 셀의 충방전 특성을 평 가하여 고찰하였다. 초음파분무-화학침전 반응으로 높은 비표면적 $\left(380 \mathrm{~m}^{2} / \mathrm{g}\right)$ 과 미약한 결정성을 가진 분말을 얻을 수 있었으며, $120^{\circ} \mathrm{C}$ 에서 24시간 동안의 추가적인 수열 합성으로 비표면적 $~ 120 \mathrm{~m}^{2} / \mathrm{g}$ 과 양호 한 결정성을 가진 양극 소재 분말을 얻을 수 있었다.

이러한 $3 \mathrm{~mol} \%$ 의 코발트를 첨가한 $\mathrm{Ni}(\mathrm{OH})_{2}$ 양극 소재에 기계화학적 환원법으로 제조한 쉬트 형상의
$\mathrm{Ni}$ 나노분말을 각각 $0,5,10 \mathrm{wt} \%$ 씩 첨가하여 제조한 양극의 전기저항은 $\mathrm{Ni}$ 첨가량이 증가함에 따라 1.0 $\Omega \cdot \mathrm{cm}$ 에서 $0.2 \Omega \cdot \mathrm{cm}$ 로 감소하였다. 이러한 전극 저 항의 감소로 인해 $\mathrm{Ni}(\mathrm{OH})_{2}$ 양극의 전압 강하가 억제 되었고 전극의 방전 특성이 $82.4 \%$ 에서 $87.4 \%$ 로 증가 하였으며, 특히 방전 에너지 밀도가 $361 \mathrm{~mW} / \mathrm{g}$ 에서 $10 \% \mathrm{Ni}$ 을 첨가에 의해서 $420 \mathrm{~mW} / \mathrm{g}$ 로 약 $17 \%$ 증가 하여, 쉬트 형상의 $\mathrm{Ni}$ 나노분말의 첨가에 의해 $\mathrm{Ni}-\mathrm{Zn}$ 레독스 플로우 전지의 양극의 충, 방전 특성이 향상 됨을 확인하였다.

\section{REFERENCES}

[1] S. Obara, Y. Morizane, and J. Morel, Int. J. Hydro. Energy, 38, 8888 (2013).

[2] P. Alotto, M. Guarnieri, and F. Moro, Renew. Sustain. Energy. Rev., 29, 325 (2014)

[3] A. Hazza, D. Pletcher, and R. Wills, Phys. Chem. Chem. Phys., 6, 1773 (2004).

[4] D. Pletcher and R. Wills, Phys. Chem. Chem. Phys., 6, 1779 (2004).

[5] D. Pletcher and R. Wills, J. Power Sources, 149, 96 (2005).

[6] H. Ahmed, D. Pletcher, and R. Wills, J. Power Sources, 149, 103 (2005).

[7] Q. Xu, T. S. Zhao, and C. Zhang, Appl. Energy, 130, 139 (2014).

[8] A. Parasuraman, T. M. Lim, C. Menictas, and M. Skyllas-Kazacos, Electrochimic Acta, 101, 27 (2013).

[9] T. Herr, P. Fischer, J. Tübke, K. Pinkwart, and P. Elsner, J. Power. Sources, 265, 317 (2014).

[10] Y. Zhang, Z. Zhou, and J. Yan, J. Power Sources, 75, 283 (1998).

[11] Q. Zhang, Y. Xu, and X. Wang, Mater. Chem. Phys., 86, 293 (2004).

[12] M. G. Ma, J. F. Zhu, J. X. Jiang, and R. C. Sun, Mater. Lett., 63, 1791 (2009).

[13] J. W. Lang, L. B. Kong, W. J. Wu, M. L. Y. C. Luo, and L. Kang, J. Solid. State. Electrochem, 13, 333 (2009).

[14] Y. Tan, S. Srinivasan, and K. S. Choi, J. Am. Chem. Soc., 127, 3596 (2005).

[15] Y. F. Yuan, X. H. Xia, J. B. Wu, J. L. Yang, Y. B. Chen, and S. Y. Guo., Electrochemical Acta, 56, 2627 (2011).

[16] W. P. Yu, X. P. Yang, L. K. Meng, and Z. Z. Liu, 
Trans. Mater. Heat Treat. (in Chinese), 26, 30 (2005).

[17] W. H. Zhu, J. J. Ke, H. M. Yu, and D. J. Zhang, J. Power Sources, 56, 75 (1995).

[18] L. K. Meng and W. P. Yu, Trans. Mater. Heat Treat. (in Chinese), 27, 17 (2006).

[19] J. Huang, Y. Lei, X. Wei, X. Liu, D. Cao, J. Yin, and G. Wang, J. Power Sources, 232, 370 (2013).

[21] G. S. Gund, D. P. Dubal, S. S. Shinde, and C. D. Lokhande, Ceramics International (2013).

[22] J. Lang, L. Kong, W. Wu, M. Liu, Y. Luo, and L. Kang, J. Solid. State. Electrochem., 13, 333 (2009).

[23] I Krejci and P. Vanysek, J. Power Sources, 47, 79 (1994). 